\title{
SiM
}

\section{Deficiencies in the Briske et al. Rebuttal of the Savory Method}

\author{
By Richard Teague
}

Clinging to past viewpoints and techniques based on a limited and small subset of knowledge on the subject of rangeland grazing management is not helpful. The knowledge base used by Briske et al. ${ }^{1}$ stems from a very poor understanding of Holistic Planned Grazing and poorly executed grazing experiments (see the work of Teague et al. ). ${ }^{2}$ To make sweeping statements such as "The Savory method cannot green deserts or reverse climate change" is particularly misleading. It ignores the fact that many ranchers operating in low rainfall areas from 10 to 15 inches, areas so bare of vegetation that most people would call them desertified, have managed to restore vegetation, ecosystem function, and productivity using Holistic Planned Grazing when even complete removal of livestock had failed to achieve any restoration. Only if the comment refers to true deserts receiving almost no rainfall would the statement possibly be true.

Many ranchers around the world have used Holistic Planned Grazing on degraded rangelands receiving less than 10 to 80 inches of annual rainfall to restore ecosystem services and productivity. When Dr Briske advises that low levels of stocking with continuous grazing are superior to rotational grazing he is possibly correct when referring to most research that has been conducted on rotational grazing. However, what Savory has advocated for more than 40 years is an entirely different thing. Savory, like Andre Voisin before him, has been critical of rotational grazing, which led him to replace all grazing systems with a holistic decision-making and planning process, namely, Holistic Planned Grazing. The folly of Dr Briske's statement is illustrated in studies from Patagonia in Argentina and Chile. The local range scientists, under the management of Dr Pablo Borelli of the Department of Agriculture, monitored range condition in detail for over 20 years on continuously grazed ranches in these dry rangelands. Every year the range condition was worse, so Dr Borelli advocated lowering the stocking rate even further. Deterioration did not stop, even in good years. Five years ago they realized this was not succeeding, so using the example of successes in Argentina and other countries, they instituted Holistic Planned Grazing on scores of ranches in the region. After just 3 years, one of which was a drought year, Dr Borelli's teams measured improvements in key ecosystem indica- tors and an improvement in animal performance, allowing for an increase in stock numbers.

Most research cited by Briske et al. ${ }^{1,3,4}$ has been short-term and has examined the issue from a reductionist viewpoint that has not included the critical influences of scale or used the best management strategies of Holistic Planned Grazing to achieve sound animal production, resource improvement, and socioeconomic goals under constantly varying conditions on rangelands. ${ }^{2}$ Concentrating only on differences in productivity without meaningfully taking into account negative impacts on the environment can lead to misleading extrapolations. Such conclusions cloud rather than enhance knowledge about sustainable grazing management and have no relevance for practical grazing management applications. Further, published multipaddock grazing research from Australia, southern Africa, Argentina, and the United States (omitted in the reviews by Briske et al.), ${ }^{1,3,4} 1$ ) conducted at the scale of ranching operations, 2) adaptively managed as conditions changed to achieve desired ecosystem and production goals, and 3) measuring parameters indicating change in ecosystem function has arrived at the opposite view to those expressed by Briske et al. ${ }^{1}$ (see Teague et al.). ${ }^{2,5}$

Selectively choosing conclusions from published papers that do not include the published data showing superior results at commercial ranch scale from Holistic Planned Grazing leads to the inferences and conclusions made by Briske et al. ${ }^{1}$ being unrepresentative of all that is known on the subject. As such, the studies they reference underestimate positive benefits to soil and ecosystem function compared to studies they have omitted, so they almost certainly underestimate the potential of the management they denigrate.

The accumulated body of small-scale grazing systems research promoted by Dr Briske and partners needs to be evaluated in light of the discrepancies with larger-scale studies, and perhaps should be largely set aside as being of little relevance to any discussion of grazing distribution on commercial ranches. Commercial ranchers operate in extensive, heterogeneous landscapes, where they are confronted with the adverse effects of uneven grazing distribution, and their collective ecological and management knowledge supports the logical reasoning employed in other articles in the Oc- 
tober 2013 Rangelands issue. NRCS policy and advice to ranchers is centered on using multipaddock, time-controlled grazing management. Their personnel are in constant contact with the best conservation ranchers as well as ranchers with rangeland in poor condition, and they appreciate the positive resource and economic value of using Holistic Planned Grazing as well as well-managed multipaddock, time-controlled grazing management.

By ignoring the body of published information indicating flaws in the grazing management research favored by Dr Briske and partners, together with ignoring the number of ranchers who win conservation awards by following the opposite advice of Dr Briske's, the adoption of conservation management by more ranchers is being set back, possibly by decades. This year SRM of Texas awarded the conservation ranch award to a rancher using a very simple four-pasture management strategy with a growing season rest every three to four years. This rancher has achieved excellent ecosystem service, productivity, and economic results despite the bad drought - an example of successful use of time-controlled grazing that every rancher would find very easy to manage. As good an example as this is, it must be noted that superior results in terms of range improvement, productivity, and profitability have been regularly obtained by ranchers using many more paddocks per herd with Holistic Planned Grazing using much shorter periods of grazing and longer recovery periods and adaptively changing recovery periods and other management elements as conditions change. ${ }^{2,5}$

In summary, it is hard to fathom how scientists can ignore the superior outcomes achieved by conservation awardwinning ranchers who use either Holistic Planned Grazing or well-managed multipaddock, time-controlled grazing. Good science involves actively seeking information that refutes any hypothesis, not rigidly defending a particular hy- pothesis and viewpoint against any dissenting viewpoint or published data.

\section{References}

1. Briske, D. D., B. T. Bestelmeyer, J. R. Brown, S. D. Fuhlendorf, and H. W. Polley. 2013. The Savory method can not green deserts or reverse climate change: a response to the Allan Savory TED video. Rangelands 35(5):72-74.

2. Teague, W. R., F. Provenza, U. Kreuter, S. Steffens, and M. BARnes. 2013. Multi-paddock grazing on rangelands: why the perceptual dichotomy between research results and rancher experience? Journal of Environmental Management 28(15):699717.

3. Briske, D., J. Derner, J. Brown, S. Fuhlendorf, R. Teague, B. Gillen, A. Ash, K. Havstad, and W. Willms. 2008. Benefits of rotational grazing on rangelands: an evaluation of the experimental evidence. Rangeland Ecology E Management 61:3-17.

4. Briske, D. D., N. F. Sayre, L. Huntsinger, M. FernandezGimenez, B. Budd, and J. D. Derner. 2011. Origin, persistence, and resolution of the rotational grazing debate: integrating human dimensions into rangeland research. Rangeland Ecology \& Management 64:325-334.

5. Teague, W. R., S. L. Dowhower, S. A. Baker, N. Haile, P. B. DeLaune, and D. M. Conover. 2011. Grazing management impacts on vegetation, soil biota and soil chemical, physical and hydrological properties in tall grass prairie. Agriculture Ecosystems and Environment 141:310-322.

Author is Professor, Ecosystem Science and Management, Texas Aङ M University, Senior Scientist of the Borlaug Institute, and Associate Resident Director, Texas AEM AgriLife Research, PO Box 1658, Vernon, TX 76385, USA, rteague@ag.tamu.edu. 